Minireview

\title{
Phycobiliproteins and phycobilisomes: the early observations
}

\author{
Nicole Tandeau de Marsac \\ Unité des Cyanobactéries, URA CNRS 2172, Département de Microbiologie Fondamentale et Médicale, \\ Institut Pasteur, 28 rue du Docteur Roux, 75724 Paris Cedex 15, France(e-mail: ntmarsac@pasteur.fr; \\ fax: +33-1-40613042)
}

Received 15 August 2002; accepted in revised form 9 October 2002

Key words: allophycocyanin, Lawrence Bogorad, K. Boresch, Donald Bryant, Germaine Cohen-Bazire, Theodor Engelmann, Nees Esenbeck, Yoshihiko Fujita, N. Gaidukov, Elisabeth Gantt, Alexander Glazer, Akihito Hattori, Harald Kylin, light-harvesting antennae, Jack Myers, Padraig O'Carra, Colm O'hEocha, photosynthesis, phycocyanin, phycoerythrin, Wolfhart Rüdiger, Hugo Scheer, H. Sorby, Nicole Tandeau de Marsac, Herbert Zuber

\begin{abstract}
The purpose of this minireview is to highlight the early observations that led to the discovery of the physicochemical properties of the phycobiliproteins, their structure and function, and to their architectural organization in supramolecular complexes, the phycobilisomes. Generally attached on the stromal surface of the thylakoid membranes in both prokaryotic (cyanobacteria) and eukaryotic cells (cyanelles, red algae and cryptomonads), these complexes represent the most abundant soluble proteins and the major light-harvesting antennae for photosynthesis. This review mainly focuses on the years prior to the development of the molecular biology of cyanobacteria that flourished in the 1980s. We refer the reader to the comprehensive and excellent review by Sidler (1994) for more recent discoveries and more detailed literature on this topic.

\section{Introduction}

As early as 1836, Nees Esenbeck described a brilliantly blue-colored, red-fluorescent, photo-labile and water-soluble pigment released by the cyanobacterium Oscillatoria sp., which he designated 'saprocyanin'. ${ }^{1}$ A few years later, Kützing (1843) renamed this pigment 'phykokyan'1 - a name more appropriate to its beautiful blue color - and he isolated a water-soluble red pigment, the 'phykoerythrin,' ${ }^{\text {from a number }}$ of red algae (Figure 1). In 1854, Sir G.G. Stokes performed the first spectroscopic analyses - important bases for the development of the concept of the Stokes shift - and noted the intense orange fluorescence of this red pigment. This observation was confirmed by Sorby (1877) who reported on the strong orange and red fluorescence of phycoerythrin and phycocyanin, respectively, from groups of red algae and the cyanobacterium Oscillatoria nigra. Sorby (1877) also provided the first evidence for allophycocyanin based on thermal denaturation studies of 'purple and pink phycocyan' solutions containing 'clean white lump (of) sugar'! In 1888, Schütt (1888) showed that wavelengths of light between $486-600 \mathrm{~nm}$ had the power of exciting fluorescence of phycoerythrin in solution, the maximum emission being situated between 560 and $590 \mathrm{~nm}$. Hanson (1909) later proposed that blue light caused the orange fluorescence of phycoerythrin which assisted light assimilation by 'degrading' it to yellow and red wavelengths corres- 


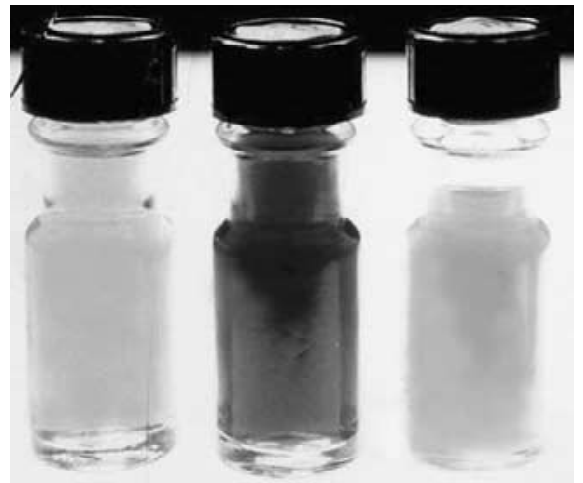

Figure 1. Purified phycobiliproteins. allophycocyanin (left), phycocyanin (center) and phycoerythrin (right). Adapted from Tandeau de Marsac, Biofutur, no. 121, 1993. For a color version of this figure, see color section in the front of the issue.

ponding to those absorbed by chlorophyll - a kind of energy transfer from phycoerythrin to chlorophyll was thus anticipated!

\section{Are phycoerythrin and phycocyanin true proteins?}

Two forms of crystals of 'rhodospermin,' obtained by Cramer (1862) from a red alga, were thirty-two years later recognized by Mölisch (1894) to be phycoerythrin. Mölisch (1895) obtained the first crystals of phycocyanin. According to Hanson (1909), phycoerythrin was '.. p probably a colloidal nitrogenous substance, related to protein, but not a true protein ....' Kylin $(1910,1912)$ succeeded in separating phycoerythrin and phycocyanin in a pure state from a red alga, analyzed their spectral characteristics and concluded from the properties of the crystals that both phycobiliproteins resembled hemoglobin in being made up of two components, one proteinaceous, as proposed by Mölisch (1895) and one pigment. The name 'phycochromoproteid,' originally proposed by Kylin, was replaced by 'phycobilin' following the work of Lemberg (1928, 1930, 1930), who found that the chromophoric groups of phycoerythrin and phycocyanin were both related to animal bile pigments. The chromophores being strongly bound to their protein counterpart, several attempts to isolate the prosthetic groups of phycocyanin and phycoerythrin generated artifacts due to degradation (for a discussion on that topic, see O'hEocha 1965). Thanks to C. O'hEocha (1958), and to many other researchers, who modified the extraction procedures and used various analytical-chemical methods, the spectral properties and structure of the chromophores, and their mode of linkage to the proteins began to be elucidated in the 1960s (for reviews, see O'hEocha 1962, 1965; Siegelman et al. 1968; Rüdiger 1970,1975; O'Carra 1970; Scheer 1981). At present, four main types of chromophores-phycoerythrobilin, phycocyanobilin, phycourobilin and phycobiliviolin-covalently bound by thioether linkages to their cognate proteins, have been characterized from red algae and cyanobacteria, and five additional ones from cryptomonads (for a review, see Sidler 1994). Three major phycobiliprotein families - the phycoerythrins, phycocyanins and allophycocyanins - are present in red algae and cyanobacteria, but only the first two are present in cryptomonads. Prefixes to phycobiliprotein classes were initially proposed by Svedberg and Katsurai (1929) to be used for distinguishing their taxonomic origin (R- for red algae, C- for cyanobacteria). However, after the discovery of two spectrally slightly different phycoerythrins in primitive red algae of the order Bangiales, B-phycoerythrin (Airth and Blinks 1956) and b-phycoerythrin (Gantt and Lipschultz 1974), the nomenclature of ' $\mathrm{R}$ ' for red algae was no longer valid. Consequently, these prefixes no more refer to the type of source organisms but denote their specific spectral characteristics.

\section{Structural units of the phycobiliproteins}

Although generally obtained as high molecular mass complexes ranging from approximately 100,000 to 208,000 daltons, T. Svedberg and co-workers (Svedberg and Lewis 1928; Svedberg and Katsurai 1929; Svedberg and Eriksson 1932) found the minimum assembly unit of phycocyanins and phycoerythrins to be about 34,700 daltons at alkaline $\mathrm{pH}$. In the 1970s, smaller and more precise values emerged from further studies of the physico-chemical properties of these phycobiliproteins. In their native forms, they were shown to consist of two dissimilar subunits, $\alpha$ $\left(M_{\mathrm{r}} 10000-19000\right)$ and $\beta\left(M_{\mathrm{r}} 14000-21000\right)$, in a 1:1 molar ratio (Bennett and Bogorad 1971; Glazer and Cohen-Bazire 1971; O'Carra and Killilea 1971; Gysi and Zuber 1974). An additional subunit of a larger molecular mass $\left(M_{\mathrm{r}} 30000\right)$ was found in Bphycoerythrin, but not in b-phycoerythrin in the red alga Porphyridium cruentum (Gantt and Lipschultz 1974).

The aggregation states for red algal and cyanobacterial phycobiliproteins in solution depend on the purification protocol and the source (i.e., the organism). 
However, with the exception of the subunit structure of B-phycoerythrin determined to be $(\alpha \beta)_{6} \gamma$ (Glazer and Hixson 1977), the most frequently found aggregation states were hexamers $(\alpha \beta)_{6}$ or trimers $(\alpha \beta)_{3}$ (Berns and Edwards 1965; Craig and Carr 1968; Neufeld and Riggs 1969; MacColl et al. 1971; Cohen-Bazire et al. 1977). The structure of the phycocyanin hexamers examined by electron microscopy revealed a round, disc-like structure of $120-130 \AA$ in diameter and 60 $\AA$ in height. Moreover, with fresh extracts of cyanobacterial cells, short rods of stacks of disc-shaped hexamers were also observed (Berns and Edwards 1965; Kessel et al. 1973)). X-ray diffraction studies by Dobler and co-workers (1972) indicated the crystal units of phycocyanin from Mastigocladus laminosus to consist of two trimers and served as a basis for the determination of the crystal structure of this phycobiliprotein at high resolution by $\mathrm{T}$. Schirmer and co-workers in the mid 1980s (for a review, see Sidler 1994).

From fluorescence polarization analyses of purified phycobiliproteins, Dale and Teale (1970) and Teale and Dale (1970) concluded that phycoerythrin and phycocyanin contain two types of chromophores, a sensitizing ('s') and a fluorescing ('f') ones. According to Alexander Glazer and co-workers (Glazer and Fang 1973a; Glazer et al. 1973), the $\beta$ and $\alpha$ phycocyanin subunits carried two s-type and one f-type chromophores, respectively, with the energy absorbed by the $\beta$ subunit being transferred, via the $\alpha$ subunit, to the next acceptor. Such a process could indeed provide an efficient directional flow of energy to the chlorophyll (Chl) $a$ located in the thylakoid membrane (for reviews, see Glazer 1976, 1989). Figure 2 shows Alexander Glazer and several other scientists involved in phycobilisome research. [See Brody (2002) and Mimuro (2002) for early energy transfer measurements.] Glazer and co-workers (Glazer et al. 1973; Glazer and Fang 1973b) were the first to perform in vitro reconstitution of a phycocyanin indistinguishable from the native protein. Importantly, these experiments demonstrated that the formation of the phycocyanin monomer $\alpha \beta$ was not accompanied by major changes in the spectra of the chromophores (Glazer 1976).

\section{Acclimation to the light intensity or to the spectral light quality?}

At the end of the 19th century, Engelmann (1883, 1884) attributed the vertical distribution of seaweeds to their ability to synthesize pigments complementary to the spectral quality of the incident light. This observation was in disagreement with Oltmanns (1892) who proposed vertical distribution to be determined by the light intensity rather that the light quality. However, the acclimation process, called by Engelmann (1902) ‘complementary chromatic adaptation' (CCA), was confirmed by further detailed studies. Gaidukov (1902, 1903a,b, 1923) showed that the cyanobacterium Oscillaria sancta became red when grown under green light and blue green after growth under orange light. Moreover, Boresch $(1919,1921)$ described that the change in color corresponded to a change in the proportion of phycoerythrin and phycocyanin, and that CCA occurred only in some cyanobacterial strains that contained phycoerythrin.

The divergent views of Engelmann and Oltmans were reconciled by Harder (1923), who proposed that pigment adaptation of seaweeds depended on both the color and intensity of the light available at different water depths, a proposal later confirmed by several groups on various algae (Brody and Emerson 1959; Jones and Myers 1965; Ghosh and Govindjee 1966; Ramus et al. 1976a,b). In these cases, however, the acclimation to the light spectral quality led to a change in the ratio of the accessory pigments to $\mathrm{Chl}$ $a$, a phenomenon called inverse chromatic adaptation that occurs in all photosynthetic organisms and differs from CCA in which Hattori and Fujita (1959a) and Fujita and Hattori (1960) showed that Tolypothrix tenuis cells specifically synthesize pigments with the highest absorbance for the incident wavelengths, i.e., phycocyanin under red light and phycoerythrin under green light. Thanks to a collection of pure cyanobacterial strains, established on R. Y. Stanier's initiative in the 1960s, a large survey by Tandeau de Marsac and Cohen-Bazire (1977) demonstrated that among chromatic adapters two groups could be distinguished. In the first group, cells modulated the synthesis of phycocyanin under red light and phycoerythrin under green light, while in the second one only the synthesis of the latter pigment was regulated.

The pioneering work of Y. Fujita and A. Hattori (Hattori and Fujita 1959a, 1959b; Fujita and Hattori 1962, 1963) revealed that CCA was controlled by a photoreversible pigment responding to green and red 

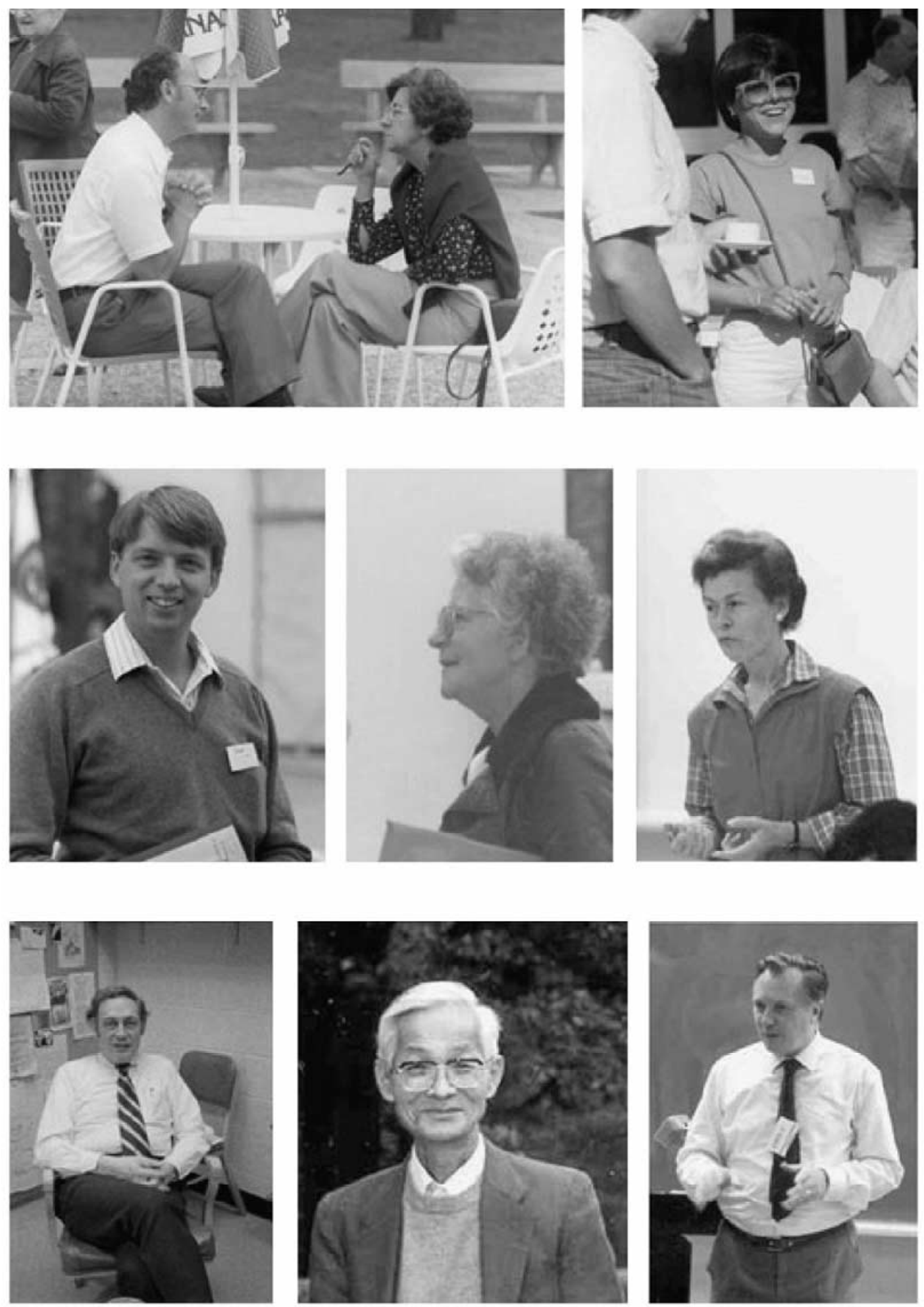

Figure 2. Alexander N. Glazer and Marcel Lefort-Tran (top left), Nicole Tandeau de Marsac (top right) Donald Bryant (middle left) and Germaine Cohen-Bazire (middle center) at the IVth International Symposium on Photosynthetic Prokaryotes in Bombannes, France, in 1982. Elisabeth Gantt (middle right) and Herbert Zuber (bottom right) at the Japan-US symposium on Phycobiliproteins in Okazaki, Japan, in 1982. Lawrence Bogorad (bottom left) in his office in 1975. Yoshihiko Fujita (bottom center) when he visited Elisabeth Gantt's laboratory in 1995. 


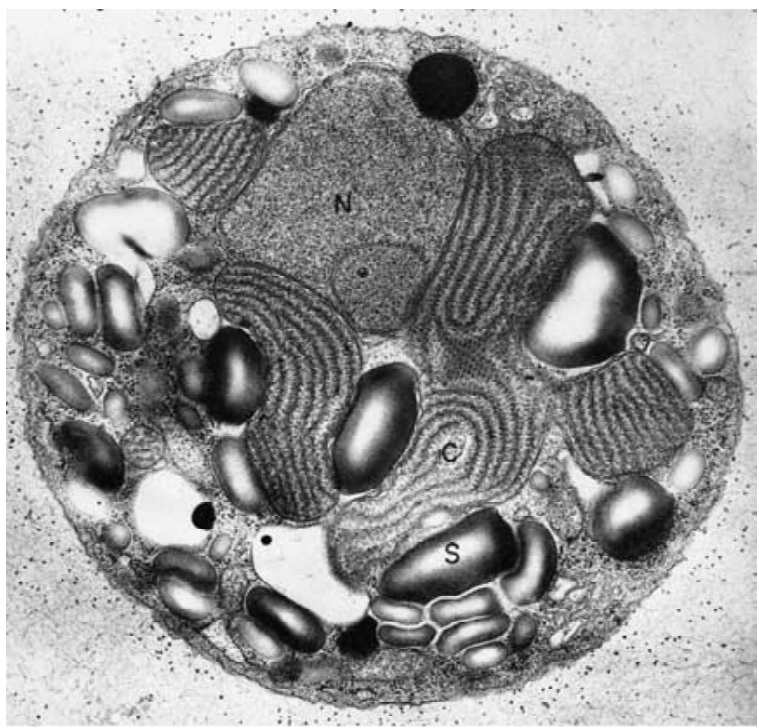

Figure 3. Electron micrograph of a section of the red alga Porphyridium cruentum. $\mathrm{N}$ - nucleus; $\mathrm{C}$ - chloroplast with phycobilisomes visible on the outside of the lamellae; $\mathrm{S}-$ starch. Reproduced from Gantt and Conti (1966).

irradiations (with maxima around $541 \mathrm{~nm}$ and $641 \mathrm{~nm}$, respectively) in Tolypothrix tenuis. These results were later confirmed by radioisotopic experiments on exponentially grown cultures of Fremyella diplosiphon (Bennett and Bogorad 1973) and by the action spectra for phycobiliprotein synthesis performed by different groups on three cyanobacterial strains (Diakoff and Scheibe 1973; Haury and Bogorad 1977; Vogelmann and Scheibe 1978; Tandeau de Marsac et al. 1980). Although the action maxima for the cyanobacterial photoreversible pigment were different $(541 / 641 \mathrm{~nm})$ from those of the plant phytochromes $(660 / 730 \mathrm{~nm})$, both photoreceptors were suspected for a long time to belong to the same protein family. It is only very recently, however, that cyanobacterial phytochromes were found in chromatic adapters (Kehoe and Grossman 1996; Herdman et al. 2000; see Grossman, this issue) and there still remain uncertainties, since, in no case, there exists a definite proof that such molecules carry a chromophore in vivo, leaving open the possibility that they may act downstream in the signaling cascade rather than in the perception of the spectral light quality.

\section{The phycobilisome: a supramolecular complex}

With the introduction of electron microscopy studies in the late 1950s, new insights were put into the structure and organization of the phycobiliproteins in vivo. The work of William Arnold and Oppenheimer (1950) indicated that phycocyanin should be separated by no more than $40 \AA$ from the membrane-bound Chl $a$ to account for the high efficiency of the energy transfer. Jack Myers and collaborators (Myers and Kratz 1955; Myers et al. 1956) noticed that phycobiliproteins were a major constituent of red algal and cyanobacterial cells, representing up to $24 \%$ of the cell dry weight in the cyanobacterium Anacystis nidulans and proposed that the $22 \mathrm{~nm}$ granules visible between thylakoids were aggregates of these pigments. In agreement with these earlier observations, excellent ultrastructural studies by Elisabeth Gantt and coworkers (Gantt and Conti 1965, 1966a, b) on the red alga Porphyridium cruentum and some cyanobacteria demonstrated that phycobiliproteins were organized in alternating macromolecular structures arranged in regular rows on the stromal surfaces of the thylakoids (Figure 3). These granules of about $400 \AA$ in diameter, twice larger than ribosomes, were given the name 'phycobilisomes' (Gantt and Conti 1966a,b). Subsequent work by Gantt and other research groups (for a review, see Gantt 1980) found a similar location and organization of the phycobiliproteins in diverse red algae and cyanobacteria.

The original method developed by Gantt and coworkers (Gantt and Conti 1966b; Gantt and Lipschultz 1972) to isolate phycobilisomes from Porphyridium cruentum was later adapted by the same group and many others to isolate these structures from diverse cyanobacteria and red algae (for a review, see Sidler 1994). Based on the examination of isolated phycobilisomes by electron microscopy, different morphological types were described: hemi-ellipsoidal, hemi-discoidal, block shaped and bundle shaped (for a review, see Sidler 1994). The latter type, which forms a cortical layer on the inner surface of the cytoplasmic membrane, was only found in an unusual cyanobacterium Gloeobacter violaceus that does not possess thylakoids (Rippka et al. 1974; Guglielmi et al. 1981).

Gantt and Lipschultz (1974) initially reported that phycobilisomes isolated from Porphyridium cruentum only consisted of phycobiliproteins with $84 \%$ B- and b-phycoerythrin, 11\% R-phycocyanin and 5\% allophycocyanin. However, in 1977, Tandeau de Marsac and Cohen-Bazire (1977) found that cyanobacterial phycobilisomes consisted of $85 \%$ of phycobiliproteins and $15 \%$ of polypeptides which, in contrast to the pigmented phycobiliproteins, were uncolored. Although accepted with doubt by some researchers, three mo- 


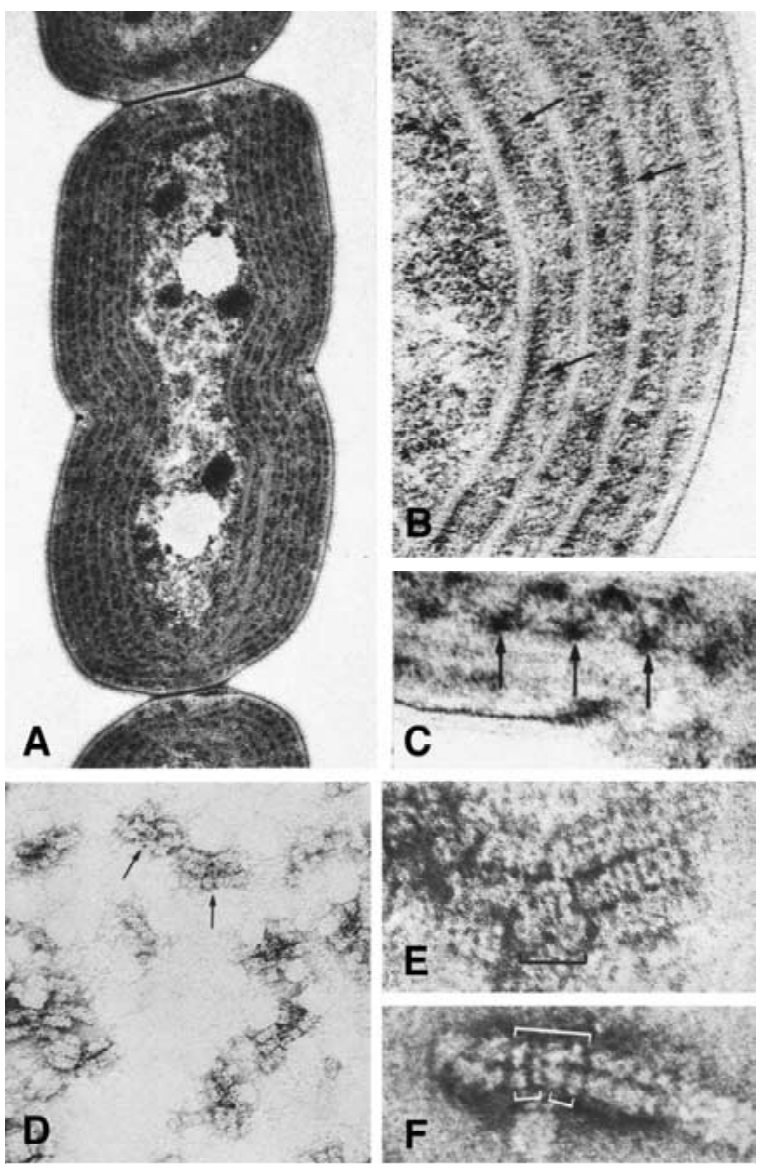

Figure 4. Electron micrographs of thin sections of cells and isolated phycobilisomes from the cyanobacterium Pseudanabaena sp. PCC 7409. (A) Dividing cell $(18000 \times)$. (B) Enlargement of a portion of a cell section perpendicular to the thylakoid surface. Rows of phycobilisomes (arrows) in longitudinal section (80000 $\times$ ). (C) Enlargement showing rows of phycobilisomes in cross section $(100000 \times)$. (D) Isolated phycobilisomes from cells grown in red light $(110000 \times)$. (E) and $(F)$. Electron micrographs of a phycobilisome isolated from cells grown in white light, in face view and base 'up,' respectively $(350000 \times)$. Adapted from Bryant et al. (1979).

lecular mass categories of linker polypeptides were confirmed to be unambiguously present in cyanobacterial and red algal phycobilisomes (for reviews, see Glazer 1984, 1989; Sidler 1994). Only the largest linker polypeptide, the core-membrane linker $\left(\mathrm{L}_{\mathrm{CM}}\right)$, was later found by Glazer's group to carry one phycocyanobilin chromophore (Lundell et al. 1981). The discovery of the linker polypeptides was rapidly followed by the description of a three-dimensional structure of phycobilisomes from cyanobacteria by Don Bryant and co-workers who coupled biochemical and electron microscopy studies (Bryant et al. 1979) (Figure 4). This first model for cyanobacterial phycobili- somes was the basis for more detailed investigations of their structure and function by Glazer's group and other laboratories (for reviews, see Glazer 1984, 1989; Sidler 1994).

\section{Phycobilisomes transfer light energy for photosynthesis}

The pioneering work of Engelmann (1881, 1882, $1883,1884)$ on the participation of chlorophyll, carotenoids and phycobiliproteins in photosynthesis led to the demonstration that phycocyanin and phycoerythrin, but not $\mathrm{Chl} a$ and carotenoids, were used to drive photosynthetic oxygen production in these particular systems. To quantify the oxygen produced by the algae exposed to light, Engelmann had the wonderful idea of using the property of aerotactic bacteria to accumulate in the area with the highest concentration of oxygen - the first 'Mikrospectrum' for photosynthesis was realized! Although perfectly correct in his conclusions, Engelmann's work was vigorously criticized by several opponents to his theories and long neglected. About 60 years later, however, the major role of the different phycobiliproteins from red algae and cyanobacteria in light-harvesting for photosynthesis was largely confirmed and quantitatively established by several groups (Emerson and Lewis 1942; Haxo and Blinks 1950; Blinks 1954; Brody and Emerson 1959; Lemasson et al. 1973). By performing high-precision action spectra, C. Lemasson and collaborators (1973) demonstrated that allophycocyanin was more efficient than phycoerythrin or phycocyanin in cyanobacteria and that $\mathrm{Chl} a$ could become the major light-harvesting pigment under nitrogen starvation. Volk and Bishop (1968) reached similar conclusions from studies of a phycocyanin-deficient mutant of a red alga.

As noted earlier, Arnold and Oppenheimer (1950) established that the migration of light energy proceeds from phycocyanin to $\mathrm{Chl} a$ by resonance energy transfer, a mechanism described by Förster two years earlier (Förster 1948). Subsequent studies by other investigators suggested that phycocyanin was an intermediate in the light energy transfer from phycoerythrin to Chl $a$ (Duysens 1951,1952; French and Young 1952). This energy transfer was shown to occur down to liquid helium temperature $(4 \mathrm{~K})$ and the temperature dependence was consistent with the Förster theory (Cho and Govindjee 1970). In the 1970s, it became clear that light energy collected by the phycobili- 
proteins within the phycobilisomes was transferred mainly to photosystem II, with allophycocyanin acting as a link between phycocyanin and the membranebound Chl a (Halldal 1970; Gantt and Lipschultz 1973; Lemasson et al. 1973). However, the detailed description of the energy transfer process within phycobilisomes awaited the work of Glazer and collaborators about 10 years later (for reviews, see Glazer 1989; Sidler 1994).

In 1925, Kitasato determined the first amino acid composition of phycoerythrin followed by others from different phycobiliprotein classes. At the dawn of the molecular biology era, a number of N-terminal sequences and the complete sequence of both subunits of phycocyanin from Mastigocladus laminosus were available (Frank et al. 1978). Their comparison, as well as physico-chemical and immunological evidence, led Glazer (for a review, see Glazer 1976) to postulate that allophycocyanin was the evolutionary ancestor of phycocyanin, which in turn preceded phycoerythrin. More recently, in the light of the comparison of complete amino acid sequences of a great number of phycobiliproteins from different spectral classes, these conclusions were revisited. A divergent phylogenetic development of the $\alpha$ - and $\beta$-subunit families from a single-subunit ancestor molecule, that gave rise to these subunit families by a gene duplication event, was assumed to reflect the evolutionary changes of the phycobiliproteins over years (for a review, see Sidler 1994).

\section{Conclusion}

For more than 150 years, phycobiliproteins and phycobilisomes were extensively studied and revealed a lot of their mystery hidden behind their glowing colors. Their remarkable physico-chemical properties, and their wonderful structure, so precisely fitted to harvest and transfer light energy to the photosynthetic reaction centers, still fascinate researchers and will certainly continue for a long time to hold captivating interest for mankind.

\section{Acknowledgments}

The author wishes to deeply thank D.A. Bryant for critical review of the manuscript and for the excellent source of references provided in his $\mathrm{PhD}$ thesis
(Bryant 1977). This minireview was edited by Govindjee.

\section{Note}

${ }^{1}$ From the Greek: 'sapros,' rotten; 'kyanos,' blue; 'phykos,' seaweed; 'erythros,' red. Phykokyan is nowadays called phycocyanin and phykoerythrin spelt phycoerythrin.

\section{References}

Airth RL and Blinks LR (1956) A new phycoerythrin from Porphyra naiadum. Biol Bull III: 321-327

Arnold W and Oppenheimer JR (1950) International conversion in the photosynthetic mechanism of blue-green algae. J Gen Physiol 33: 423-435

Bennett A and Bogorad L (1971) Properties of subunits and aggregates of blue-green algal biliproteins. Biochemistry 10: 3625-3634

Bennett A and Bogorad L (1973) Complementary chromatic adaptation in a filamentous blue-green alga. J Cell Biol 58: 419-435

Berns DS and Edwards MR (1965) Electron micrographic investigations of C-phycocyanin. Arch Biochem Biophys 110: 511-516

Blinks LR (1954) The photosynthetic function of pigments other than chlorophyll. Annu Rev Plant Physiol 5: 93-114

Boresch K (1919) Über die Einwirkung farbigen Lichtes auf die Färbung von Cyanophyceen. Ber Deutsch Bot Ges 37: 25-39

Boresch K (1921) Die komplementäre chromatische adaptation. Arch Protistenk 44: 1-70

Brody M and Emerson R (1959) The quantum yield of photosynthesis in Porphridium cruentum, and the role of chlorophyll $a$ in the photosynthesis of red algae. J Gen Microbiol 43: 251-264

Brody SS (2002) Fluorescence lifetime, yield, energy transfer and spectrum in photosynthesis, 1950-1960. Photosynth Res 73: $127-132$

Bryant DA (1977) Comparative studies on cyanobacterial and rhodophytan biliproteins. $\mathrm{PhD}$ dissertation, University of California, Los Angeles

Bryant DA, Guglielmi G, Tandeau de Marsac N, Castets AM and Cohen-Bazire G (1979) The structure of cyanobacterial phycobilisomes: A model. Arch Microbiol 123: 113-127

Cho F and Govindjee (1970) Low temperature (4-77K) spectroscopy of Anacystis: temperature dependence of energy transfer efficiency. Biochim Biophys Acta 216: 151-161

Cohen-Bazire G, Béguin S, Rimon S, Glazer AN and Brown DM (1977) Physico-chemical and immunological properties of allophycocyanins. Arch Microbiol 111: 225-238

Craig IW and Carr NG (1968) C-phycocyanin and allophycocyanin in two species of blue-green algae. Biochem J 106: 361-366

Cramer C (1862) Das Rhodospermin, ein krystalloidischer, quellbarer Körper, im Zellinhalt verschiedener Florideen. Vierteljahrsschr Naturforsch Ges Zurich 7: 350-365

Dale RE and Teale FWJ (1970) Number and distribution of chromophore types in native phycobiliproteins. Photochem Photobiol 12: 99-117

Diakoff S and Scheibe J (1973) Action spectra for chromatic adaptation in Tolypothrix tenuis. Plant Physiol 51: 382-385

Dobler M, Dover SD, Laves K, Binder A and Zuber H (1972) Crystallization and preliminary crystal data of $C$-phycocyanin. J Mol Biol 71: 785-787 
Duysens LNM (1951) Transfer of light energy within the pigment systems present in photosynthesizing cells. Nature 168: 548-550

Duysens LNM (1952) Transfer of energy in photosynthesis. Doctoral thesis, State University Utrecht, The Netherlands

Eiserling FA and Glazer AN (1974) Blue-green algal proteins: assembly forms of C-phycocyanin from Synechococcus sp. J Ultrastruct Res 47: 16-25

Emerson R and Lewis CM (1942) The photosynthetic efficiency of phycocyanin in Chroococcus, and the problem of carotenoid participation in photosynthesis. J Gen Physiol 25: 579-595

Engelmann TW (1881) Neue Methode zur Untersuchung der Sauerstoffausscheidung pflanzlicher und thierischer Organismen. Bot Z 39: 441-448

Engelmann TW (1882) Ueber Sauerstoffausscheidung von Pflanzenzellen im Mikrospectrum. Bot Z 40: 419-425

Engelmann TW (1883) Farbe und Assimilation. I. Assimilation findet nur in den farbstoffhaltigen Plasmatheilchen statt. II. Näherer Zusammenhang zwischen Lichtabsorption und Assimilation. III. Weitere Folgerungen. Bot Z 41: 1-29

Engelmann TW (1884) Untersuchungen über die qualitativen Beziehungen zwischen Absorption des Lichtes und Assimilation in Pflanzenzellen. I. Das Mikrospectraphotometer, ein Apparat zur quantitativen Mikrospectralanalyse. II. Experimentelle Grundlagen zur Ermittelung der quantitativen Beziehungen zwischen Assimilationsenergie und Absorptiongrösse. III. Bestimmung der Vertheilung der Energie im Spectrum von Sonnenlicht mittels Bacterien-Methode und quantitativen Mikrospectralanalyse. Bot Z 42: 81-105

Engelmann TW (1902) Ueber experimentelle erzeugung zweckmässiger aenderungen der färbung pflanzlicher chromophylle durch farbiges licht. Arch Anat Physiol (Physiol Abt): 333-335

Esenbeck N (1836) Ueber einen blau-rothen Farbstoff, der sich bei der Zersetzung von Oscillatorien bildet. Liebigs Ann Chem XVII: 75-82

Förster T (1948) Zwischenmolekulare Energiewanderung und Fluoreszenz. Ann Physik 2: 55-75

Frank G, Sidler W, Widmer H and Zuber H (1978) The complete amino acid sequence of both subunits of C-phycocyanin from the cyanobacterium Mastigocladus laminosus. Hoppe Seyler's Z Physiol Chem 359: 1491-1507

French CS and Young VK (1952) The fluorescence spectra of red algae and the transfer of energy from phycoerythrin to phycocyanin and chlorophyll. J Gen Physiol 35: 873-890

Fujita Y and Hattori A (1960) Effect of chromatic lights on phycobilin formation in a blue-green alga Tolypothrix Tenuis. Plant Cell Physiol 1: 293-303

Fujita Y and Hattori A (1962) Photochemical interconversion between precursors of phycobilin chromoproteids in Tolypothrix tenuis. Plant Cell Physiol 3: 209-220

Fujita Y and Hattori A (1963) Effects of second chromatic illumination on phycobilin chromoprotein formation in chromatically preilluminated cells of Tolypothrix tenuis. Plant Cell Physiol (special issue on Microalgae \& Photosynthetic Bacteria): 431440

Gaidukov N (1902). Über den Einfluss farbigen Lichtes auf die Färbung der Oscillarien. Abh Preuss Akad Wiss V: 8-13

Gaidukov N (1903a) Die Farbenveränderung bei den Prozessen der komplementären chromatischen Adaptation. Ber Deutsch Bot Ges 21: 517-522

Gaidukov N (1903b) Weitere Untersuchungen Über den Einfluss farbigen Lichtes auf die Färbung der Oscillarien. Ber Deutsch Bot Ges 21: 484-492

Gaidukov N (1923) Zur Frage nach der komplementären chromatischen Adaptation. Ber Deutsch Bot Ges 41: 356-361
Gantt E (1980) Structure and function of phycobilisomes: lightharvesting pigment complexes in red and blue-green algae. Int Rev Cytol 66: 45-80

Gantt E and Conti SF (1965) The ultrastructure of Porphyridium cruentum. J Cell Biol 26: 365-381

Gantt E and Conti SF (1966a) Granules associated with the chloroplast lamellae of Porphyridium cruentum. J Cell Biol 29: 423434

Gantt E and Conti SF (1966b) Phycobiliprotein localization in algae. Brookhaven Symp Biol 19: 393-405

Gantt E and Lipschultz CA (1972) Phycobilisomes of Porphyridium cruentum. I. Isolation. J Cell Biol 54: 313-324

Gantt E and Lipschultz CA (1973) Energy transfer in phycobilisomes from phycoerythrin to allophycocyanin. Biochim Biophys Acta 292: 858-861

Gantt E and Lipschultz CA (1974) Phycobilisomes of Porphyridium cruentum: Pigment analysis. Biochemistry 13: 2960-2966

Ghosh AK and Govindjee (1966) Transfer of excitation energy in Anacystis nidulans grown to obtain different pigment ratios. Biophys J 6: 611-619

Glazer AN (1976) Phycocyanins: Structure and Function. In: Smith KC (ed) Photochemical and Photobiological Reviews, Vol 1, pp 71-115. Plenum Publishing, New York

Glazer AN (1984) Phycobilisome. A macromolecular complex optimized for light energy transfer. Biochim Biophys Acta 768: 29-51

Glazer AN (1989) Light guides. Directional energy transfer in a photosynthetic antenna. J Biol Chem 264: 1-4

Glazer AN and Cohen-Bazire G (1971) Subunit structure of the phycobiliproteins of blue-green algae. Proc Natl Acad Sci USA 68: 1398-1401

Glazer AN and Fang S (1973a) Chromophore content of blue-green algal phycobiliproteins. J Biol Chem 248: 659-662

Glazer AN and Fang S (1973b) Formation of hybrid proteins from the $\alpha$ and $\beta$ subunits of phycocyanins of unicellular and filamentous blue-green algae. J Biol Chem 248: 663-671

Glazer AN and Hixson CS (1977) Subunit structure and chromophore composition of Rhodophytan phycoerythrins. Porphyridium cruentum B-phycoerythrin and b-phycoerythrin. J Biol Chem 252: 32-42

Glazer AN, Fang S and Brown DM (1973) Spectroscopic properties of C-phycocyanin and of its $\alpha$ and $\beta$ subunits. J Biol Chem 16: 5679-5685

Grossman A (2003) A molecular understanding of complementary chromatic adaptation. Photosynth Res 76: 207-215 (this issue)

Guglielmi G, Cohen-Bazire G and Bryant DA (1981) The structure of Gloeobacter violaceus and its phycobilisomes. Arch Microbiol 129: 181-189

Gysi J and Zuber H (1974) Isolation and characterization of allophycocyanin II from the thermophilic blue-green alga Mastigocladus laminosus Cohn. FEBS Lett 48: 209-213

Halldal P (1970) The photosynthetic apparatus of microalgae and its adaptation to environmental factors. In: Halldal P (ed) Photobiology of Microorganisms, Chap 2, pp 17-55. Wiley, London

Hanson EK (1909) Observations on phycoerythrin, the red pigment of deep-water algae. New Phytol 8: 337-344

Harder R (1923) Über die Bedeutung von Lichtintensität und Wellenlänge für die Assimilation farbiger Algen. Z Bot XV: 305-355

Hattori A and Fujita Y (1959a) Formation of phycobilin pigments in a blue-green alga, Tolypothrix tenuis, as induced by illumination with colored lights. J Biochem 46: 521-524

Hattori A and Fujita Y (1959b) Spectroscopic studies on the phycobilin pigments obtained from blue-green and red algae. J Biochem 46: 903-909 
Haury JF and Bogorad L (1977) Action spectra for phycobiliprotein synthesis in a chromatically adapting cyanophyte, Fremyella diplosiphon. Plant Physiol 60: 835-839

Haxo FT and Blinks LR (1950) Photosynthetic action spectra of marine algae. J Gen Physiol 33: 389-422

Herdman M, Coursin T, Rippka R, Houmard J and Tandeau de Marsac N (2000) A new appraisal of the prokaryotic origin of eukaryotic phytochromes. J Mol Evol 51: 205-213

Jones LW and Myers J (1965) Pigment variations in Anacystis nidulans induced by light of selected wavelengths. J Phycol 1: 6-13

Kehoe DM and Grossman AR (1996) Similarity of a chromatic adaptation sensor to phytochrome and ethylene receptors. Science 273: 1409-1412

Kessel M, MacColl R, Berns DS and Edwards MR (1973) Electron microscope and physical chemical characterization of $\mathrm{C}$ phycocyanin from fresh extracts of two blue-green algae. Can J Microbiol 19: 831-836

Kitasato Z (1925) Biochemische Studien über Phycoerythrin und Phycocyan. Acta Phytochem 2: 75-97

Kützing FT (1843) Phycologia generalis, oder Anatomie, Physiologie und Systemkunde der Tange. FA Brockhaus, Leipzig

Kylin H (1910) Über Phykoerythrin und Phykocyan bei Ceramium rubrum (Huds.) Ag. Hoppe-Seyler's Z Physiol Chem LXIX: 169-239

Kylin H (1912) Über die roten und blauen Farbstoffe der Algen. Hoppe-Seyler's Z Physiol Chem LXXVI: 396-425

Lemasson C, Tandeau de Marsac N and Cohen-Bazire G (1973) Role of allophycocyanin as a light-harvesting pigment in cyanobacteria. Proc Natl Acad Sci USA 70: 3130-3133

Lemberg R (1928) Die chromoproteide der rotalgen. I. Liebigs Ann Chem 461: 46-89

Lemberg R (1930) Chromoproteide der Rotalgen. II. Spaltung mit pepsin un säuren. Isolierung eines pyrrolfarbstoffs. Liebigs Ann Chem 477: 195-245

Lemberg R and Bader G (1933) Die phycobiline der rot-algen. Überführung in mesobilirubin und dehydro - mesobilirubin. Liebigs Ann Chem 505: 151-177

Lundell DJ, Yamanaka G and Glazer AN (1981) A terminal energy acceptor of the phycobilisome: the 75000 -dalton polypeptide of Synechococcus 6301 phycobilisomes - a new biliprotein. J Cell Biol 91: 315-319

MacColl R, Lee JJ and Berns DS (1971) Protein aggregation in C-phycocyanin - studies at very low concentration with the photoelectric scanner of the ultracentrifuge. Biochem $\mathrm{J}$ 122: 421-426

Mimuro M (2002) Visualization of excitation energy transfer processes in plants and algae. Photosynth Res 73: 133-138

Mölisch H (1894) Das phycoerythrin, seine Krystallisirbarkeit und chemische Natur Bot Z 52: 177-189

Mölisch H (1895) Das Phycocyan, ein krystallisirbarer Eiweisskörper. Bot Z 53: 131-135

Myers A, Preston RD and Ripley GW (1956) Fine structure in the red algae - I. X-ray and electronmicroscope investigation of Griffithsia flosculosa. Proc R Soc London Ser B 144: 450-459

Myers J and Kratz WA (1955) Relations between pigment content and photosynthetic characteristics in a blue-green alga. J Gen Microbiol 39: 11-22

Neufeld GJ and Riggs AF (1969) Aggregation properties of Cphycocyanin from Anacystis nidulans. Biochem Biophys Acta 181: 234-243

O’Carra P (1970) Algal biliproteins. Biochem J 119: 2-3
O'Carra P and Killilea SD (1971) Subunit structures of Cphycocyanin and C-phycoerythrin. Biochem Biophys Res Commun 45: 1192-1197

O'hEocha C (1958) Comparative biochemical studies of the phycobilins. Arch Biochem Biophys 73: 207-219

O'hEocha C (1962) Phycobilins. In: Lewin RA (ed) Physiology and Biochemistry of Algae, Chap 2, pp 421-425. Academic Press, New York

O’hEocha C (1965) Biliproteins of algae. Annu Rev Plant Physiol 16: $415-434$

Oltmanns F (1892) Ueber die Cultur- und Lebensbedingungen der Meeresalgen. Jahrb wiss Botany 23: 349-440

Ramus J, Beale SI, Mauzzerall D and Howard KL (1976a) Changes in photosynthetic pigment concentration in seaweeds as a function of water depth. Marine Biol 37: 223-229

Ramus J, Beale SI and Mauzzerall D (1976b) Correlation of changes in pigment content with photosynthetic capacity of seaweeds as a function of water depth. Marine Biol 37: 231-238

Rippka R, Waterbury J and Cohen-Bazire G (1974) A cyanobacterium which lacks thylakoids. Arch Microbiol 100: 419-436

Rüdiger W (1970) Recent chemistry and biochemistry of bile pigments. Angew Chem Int Ed 9: 473-480

Rüdiger W (1975) Phycobiliproteide. Ber Deutsch Bot Ges 88: 125 139

Scheer H (1981) Biliproteins. Angew Chem Int Ed Engl 20: 241261

Schütt F (1888) Weitere Beiträge zur Kenntniss des Phycoerythrins. Ber Deutsch Bot Ges VI: 305-323

Sidler WA (1994) Phycobilisome and phycobiliprotein structures. In: Bryant DA (ed) The Molecular Biology of Cyanobacteria, Chap 7, pp 139-216. Kluwer Academic Publishers, Dordrecht, The Netherlands

Siegelman HW, Chapman DJ and Cole WJ (1968) The bile pigments of plants. In: Goodwin TW (ed) Biochemical Society Symposia, Vol 28, pp 107-120. Academic Press, New York

Sorby HC (1877) On the characteristic colouring-matters of the red groups of algae. J Linnean Soc Bot XV: 34-40

Stokes GG (1854) Über die Metallreflexion an gewissen nichtmetallischen Sub-stanzen. Ann Phys Chem (Poggendorff JC) 4: 300-313

Svedberg T and Eriksson IB (1932) The molecular weights of phycocyan and of phycoerythrin. III. J Am Chem Soc 54: 3998-4010

Svedberg T and Katsurai T (1929) The molecular weights of phycocyan and of phycoerythrin from Porphyra tenera and of phycocyan from Aphanizomenon flos aquae. J Am Chem Soc 51: 3573-3583

Svedberg T and Lewis NB (1928) The molecular weights of phycoerythrin and of phycocyan. J Am Chem Soc 50: 525-536

Tandeau de Marsac N and Cohen-Bazire G (1977) Molecular composition of cyanobacterial phycobilisomes. Proc Natl Acad Sci USA 74: 1635-1639

Tandeau de Marsac N, Castets AM and Cohen-Bazire G (1980) Wavelength modulation of phycoerythrin synthesis in Synechocystis sp. 6701. J Bacteriol 142: 310-314

Teale FWJ and Dale RE (1970) Isolation and spectral characterization of phycobiliproteins. Biochem J 116: 161-169

Vogelmann TC and Scheibe J (1978) Action spectra for chromatic adaptation in the blue-green alga Fremyella diplosiphon. Planta 143: 233-239

Volk SL and Bishop NI (1968) Photosynthetic efficiency of a phycocyanin-less mutant of Cyanidium. Photochem Photobiol 8: 213-221 